\title{
Analisis Faktor-Faktor yang Mempengaruhi Kinerja Kepala Desa di Kabupaten Kuantan Singingi dan Kabupaten Kampar
}

\author{
Sonia Sischa Eka Putri ${ }^{1}$, Pivit Septiary Chandra ${ }^{2}$, Arridho Abduh ${ }^{3}$ \\ Universitas Islam Negeri Sultan Syarif Kasim Riau ${ }^{1,2,3)}$ \\ Sonia.sischa@uin-suska.ac.id, pivit.s.chandra@uin-suska.ac.id, $\underline{\text { arridhoabduh@uin-suska.ac.id }}$ \\ *Corresponding Author \\ Diajukan : 28 April 2021 \\ Diterima : 9 Juli 2021 \\ Dipublikasikan : 1 Juli 2021
}

\begin{abstract}
This study aims to see the effect of clarity of budget targets, internal control systems, motivation and organizational commitment to the performance of village heads in Kuantan Singingi and Kampar districts. This research was conducted in 2020 to see the performance of the village head, this is because there are still problems related to the performance of the village head that the community complains about, therefore the authors want to measure whether the clarity of budget targets, internal control systems, motivation and organizational commitment have an effect on the performance of the village head. The type of data used is primary data by using questionnaire method of data collection.. The sample in this study were village heads totaling 60 people. The results of this study indicate that the clarity of budget targets has an influence on the performance of the village head, the internal control system has an influence on the performance of the village head, motivation and organizational commitment also has an influence on the performance of village heads in Kuantan Singingi and Kampar Districts. From all the testingist done it can be concluded that the variables of budget targets, internal control systems, motivation and organizational commitment that it used to explain $63 \%$ of villages head performance. While there meaning $37 \%$ are influence do rexplained by other variables not included in this study.
\end{abstract}

Keywords: Performance; clarity of budget targets; internal control system; motivation; organizational commitment

\section{PENDAHULUAN}

Pada masa pemerintahan yang semakin berkembang kearah yang positif ini, pembangunan merata dalam sebuah Negara merupakan isu sentral yang sedang ramai dibicarakan. Paradigma pembangunan di Indonesia tidak hanya berfokus pada pusat saja, saat ini pembangunan desa juga menjadi pembangunan vital yang diperhatikan. Pemerintah telah menerapkan berbagai macam kebijakan dan program yang akan disalurkan kepada masyarakat di desa, program desa ini mencakup program dana desa, program Indonesia sehat hingga program keluarga harapan. Program yang diluncurkan oleh pemerintah ini diharapkan akan mengatasi masalah kesenjangan ekonomi, kemiskinan dan masyarakat tertinggal di desa. Kegiatan yang dilakukan tersebut lebih memberatkan pada titik peningkatan pelayanan, peningkatan kualitas sumber daya manusia, percepatan pembangunan desa dan peningkatan pertumbuhan ekonomi desa.

Berbagai cara digesa oleh pemerintah Indonesia guna meningkatkan pertumbuhan desa dari berbagai sector, salah satunya dengan memberikan fasilitas dana desa. Kebijakan penganggaran dana desa yang bersumber dari Anggaran Pendapatan dan Belanja Negara (APBN) telah giat dilakukan pemerintah sejak tahun 2015. Perangkat desa yang mewakili pengelolaan dana desa ini diwakili oleh kepala desa dan jajarannya. Mereka dituntut untuk dapat mengelola anggaran yang telah dikucurkan secara efektif dan efisien. Peningkatan peayanan public di desa, meminimalisir kesenjangan ekonomi, memajukan perekonomian desa, mengatasi kesenjangan pembangunan antar 
desa serta memperkuat masyarakat desa sebagai subjek dari pembangunan (UU No. 6 Tahun 2014 Tentang Desa). Tujuan yang telah dideskripsikan dalam undang-undang tersebut dapat tercapai dengan bantuan kinerja yang akan dihasilkan oleh kepala desa, kinerja kepala desa yang baik akan memberikan implikasi positif bagi kemajuan desa itu sendiri.

Pondasi pencapaian yang dititikberatkan pada kinerja yang dihasilkan oleh kepala desa dapat terlihat dari kepuasan masyarakat akan pelayanan yang diberikan dan peningkatan kesejahteraan masyarakat desa. Namun kondisi dilapangan cenderung bertolak belakang dengan banyaknya ditemui kasus-kasus buruknya pelayanan public dan tidak tercapainya kepuasan masyarakat desa. Hal ini terlihat berdasarkan data yang dirilis oleh website https://www/ombudsman.go.id melalui layanan pengaduan berupa Layanan Aspirasi dan Pengaduan Online Rakyat atau yang biasa disebut dengan LAPOR terdapat banyak sekali pengaduan masyarakat terkait lemahnya kinerja desa. Selain keluhan masyarakat terhadap kinerja kepala desa yang kurang baik, Indonesian Corruption watch (ICW) juga memperhatikan peningkatan tingkat korupsi yang terjadi di desa, tercatat tingkat korupsi tertinggi terjadi pada tahun 2019 dengan dana desa menyumbang 46 kasus korupsi dan merugikan negara hingga Rp. 32,3 Miliar.

Terdapat banyak golongan masyarakat yang mengeluh dengan pelayanan yang diberikan desa dalam hal pelayanan public mulai dari pembuatan KTP yang berbelit-belit, tidak disiplinnya perangkat desa dalam jam kerja, hingga pendelegasian wewenang dan tugas yang tidak jelas antar perangkat desa (Roberto, 2019)

Guna tercapainya tujuan utama dari pengalokasian dana desa, dibutuhkan kejelasan sasaran anggaran sebagai alat percepatan pencapaiannya. Kejelasan target akan sejauh mana anggaran telah ditetapkan secara jelas dan spesifik akan mempermudah orang yang bertanggungjawab dalam mengelolanya untuk mencapai sasaran tersebut. Penelitian yang dilakukan oleh peneliti terdahulu dengan variable kejelasan sasaran anggaran masih tidak konsisten. (Putra, 2013) kejelasan sasaran anggaran berpengaruh signifikan positif terhadap kinerja manajerian Satuan Kerja Perangkat Daerah (SKPD), kejelasan sasaran anggaran bida menjadi tolak ukur pencapaian kinerja yang diharapkan, sehingga dalam perencanaan anggaran harus dapat menggambarkan sasaran kinerja secara jelas. Hal ini didukung oleh Darma (2013). Hasil penelitian ini justru kontradiksi dengan penelitian yang dilakukan oleh (Nurhalimah et al., 2013)bahwa kejelasan sasaran anggaran tidak berpengaruh terhadap kinerja aparatur daerah dikarenakan perangkat daerah belum bias memahami anggaran dengan jelas sehingga sulit untuk dipahami. Hasil penelitian ini didukung oleh (Pilipus, 2009).

Sistem pengendalian internal berfungsi sebagai alat untuk mengelola organisasi secara efektif dan efisien guna tercapainya tujuan organisasi. Hal ini sesuai dengan penelitian yang dilakukan oleh Putri (2018) menyatakan bahwa pengendalian intern berpengaruh pada kinerja pegawai di organisasi perangkat daerah. Hal ini didukung oleh penelitian (Afrida, 2013) bahwa pengendalian intern pemerintah berpengaruh signifikan positif terhadap kinerja manajerial. Hal ini bertolak belakang dengan hasil penelitian yang dilakukan oleh (Fahdi, 2015) dimana pengendalian intern tidak berpengaruh terhadap kinerja BLU.

Motivasi adalah proses yang menjelaskan intensitas, arah dan ketekunan sesorang untuk mencapai tujuannya. Hal ini berkaitan langsung dengan kinerja setiap individu karyawan, dimana motivasi yang tinggi akan secara otomatis meningkatkan laju kinerja yang dihasilkan(Oluseyi \& Hammed, 2009) meneliti kinerja pegawai pemerintah Nigeria, dimana motivasi memiliki dampak terhadap kinerja, hal ini didukung oleh (Kumar \& Garg, 2011). Namun, penelitian tersebut memiliki hasil yang berbanding terbalik dengan (Pridarsanti \& Yuyetta, 2013) dimana motivasi tidak memiliki pengaruh signifikan terhadap kinerja pegawai Dirjen Perbendaharaan kementrian keuangan Kota Semarang.

Komitmen organisasi merupakan salah satu hal yang harus ditanamkan dalam diri setiap pegawai, dimana komitmen organisasi yang rendah cenderung memberikan dampak terhadap kinerja yang akan dihasilkan. Rasa bertanggungjawab terhadap setiap kewajiban yang diampu akan memberikan efek positif. (Nazaruddin \& Setyawan, 2016)menyatakan bahwa komitmen organisasi tidak berpengaruh terhadap kinerja pemerintah daerha, hal ini tidak sejalan dengan Fahdi (2015), (Wulandari, 2013) yang menyatakan bahwa komitmen organisasi memiliki pengaruh terhadap kinerja pegawai. 


\section{Deskripsi Teori \\ Kinerja}

\section{STUDI LITERATUR}

(Mangkunegara, 2016) Kinerja (performance) merupakan prestasi yang telah dicapai oleh individu yang dilihat dari hasil kerja keseluruhan yang telah dihasilkan individu secara berkelompok maupun tidak. Prestasi kerja yang berkualitas dan kuantitas yang baik yang dicapai oleh seorang pegawai dala melaksanakan tanggung jawabnya dapat dibedakan menjadi duam yakni kinerja individu pegawai dan kinerja organisasi. Kinerja individu merupakan kinerja karyawan yang dilakukan sesuai dan berlandaskan standar yang telah dilakukan. Sedangkan kinerja organisasi merupakan kinerja yang dihasilkan dari keseluruhan kinerja individu dalam sebuah organisasi atau sebuah kelompok.

\section{Kejelasan Sasaran Anggaran}

Sasaran merupakan segala sesuatu yang hendak dicapai oleh karyawan. Kejelasan sasaran anggaran adalah hal-hal yang akan mendorong individu agar mencapai target sasaran yang lebih efektif dan memberikan upaya yang lebih maksimal dalam pelaksanaannya (Locke \& Latham, 1984). Kejelasan sasaran anggaran merupakan keterlibatan setiap individu dalam penyusunan anggaran, sehingga setiap orang akan dapat memhami sasaran anggaran yang akan dicapai, strategi pencapaiannya, serta sumber daya apa yang dibutuhkan dalam suatu instansi. Kejelasan sasaran anggran juga menjadi tolak ukur dalam penilaian kinerja dan pencapaian yang diharapkan (Kenis, $\underline{1979)}$

\section{Pengendalian Internal}

Dalam standar profesional akuntan publik (SPAP) pengendalian internal pemerintah didefinisikan sbeagai: " Pengendalian internal meliputi struktur organisasi, metoda dan ukuranukuran yang digunakan guna tercapainya tujuan, mengecek ketelitian serta keandalan data akuntansi, mendorong efisiensi, menjaga kekayaan organisasi dan dipatuhinya kebijakan pimpinan". Menurut (PP No. 60 tahun 2008), sistem pengendalian internal merupakan proses yang integral yang dilakukan secara terus menerus oleh pimpinan organisasi dan juga keseluruhan pegawai guna memberikan keyakinan akan tercapainya tujuan organisasi melalui kegiatan yang efektif dan efisien, keandalan pelaporan keuangan, pengamanan aset negara dan ketaatan pada peraturan perundang-undangan yang berlaku.

\section{Motivasi}

Menurut (Mowday et al., 1979) motivasi merupakan keadaan dimana setiap individu memiliki rasa kesediaan melakukan usaha tingkat tinggi guna mencapai sasaran organisasi yang dikondisikan oleh kemampuan uasaha yang dilakukan dalam memberikan kepuasan individu, yang dipengaruhi oleh: Kebutuhan prestasi, kekuasaan dan kebutuhan akan afiliasi.

\section{Komitmen Organisasi}

Komitmen organisasi cenderung didefinisikan sebagai suatu paduan sikap dan prilaku dalam mengelola sumber daya manusia. Tingkat penanaman komitmen dalam diri setiap karyawan akan menentukan kinerja yang akan dihasilkan oleh karyawan tersebut. (Aisyah, n.d.)kinerja pegawai sektor publik dapat optimal apabila didukung oleh komitemn organisasi baik dari segi individu pegawai maupun di dorong oleh pejabat pemerintahan. Faktor pendukungnya dapat terlihat dari: Rasa identifikasi dengan tujuan organisasi, rasa keterlibatan dan rasa kesetiaan terhadap organisasi.

\section{Kerangka Konseptual}

Kerangka konseptual dalam penelitian ini dibuat berlandaskan pada permasalahan yang terjadi, keterkaitan variabel secara teoritis, dan kajian-kajian dari penelitian terdahulu. Kerangka konseptual yang dibangun diharapkan dapat mendeskripsikan tentang penelitian yang akan dilakukan oleh peneliti, yakni guna menganalisis faktor-faktor yang mempengaruhi kinerja aparatur desa. Model penelitian dapat dilihat dari gambar 1 berikut:

Kejelasan Sasaran Anggaran (X1) 


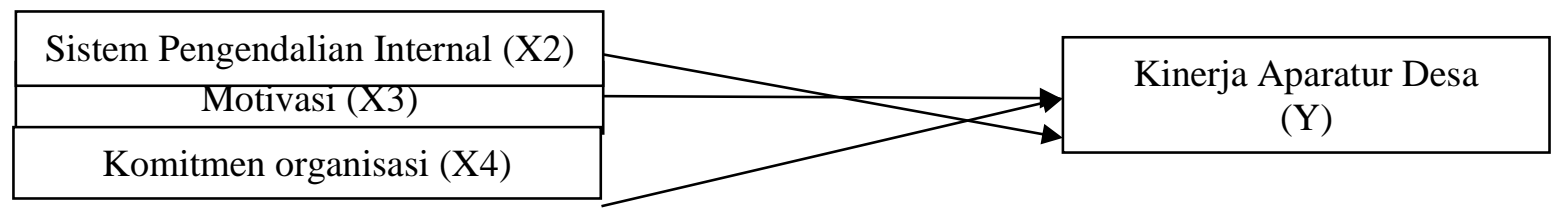

\section{Hipotesis Penelitian}

Gambar 1. Model Penelitian

\section{Pengaruh kejelasan sasaran anggaran terhadap kinerja kepala desa}

Dalam konteks pemerintahan daerah, kejelasan sasaran angaran menyebabkan aparat desa dapat dengan lebih mudah mengakses dan menyusun anggaran sesuai dengan tingkat pencapaian sasaran yang diharapkan. Aparatur ddaerah dapat memiliki informasi yang cukup untuk memprediksi anggaran dalam jangka panjang secara tepat. Sehingga kesenjangan anggaran akan semakin berkurang dan kinerja manajerial aparat semakin baik saat sasaran anggaran sudah ditetapkan secara jelas.(Muzahid, 2017)Penelitian yang dilakukan oleh Putra (2013) memiliki hasil bahwa kejelasan sasaran anggaran berpengruh signifikan positif terhadap kinerja manajerial Satuan Kerja Perangkat Daerah (SKPD). Hasil penelitian ini didukung oleh (Darma, 2013)

H1 : Kejelasan sasaran anggaran berpengaruh terhadap kinerja Kepala Desa .

\section{Pengaruh Sistem Pengendalian Internal Terhadap Kinerja Kepala Desa}

Dalam PP No. 60 Tahun 2008 menyatakan bahwa system pengendalian internal merupakan proses yang dilakukan secara terus menerus yang dilakukan oleh pimpinan organisasi hingga keseluruhan pegawai guna memberikan keyakinan memadai untuk tercapaiya tujuan organisasi dengan program dan kegiatan yang efektif dan efisien, keandalan pelaporan keuangan, pengamanan asset negra hingga ketaatan pada peraturan perundang-undangan. Hal ini sesuai dengan penelitian yang dilakukan oleh (Putri et al., n.d.) bahwa Sistem pengendalian internal berpengaruh terhadap kinerja pegawai, penelitian ini didukung dengan penelitian yang dilakukan Darma (2013).

$\mathrm{H} 2$ : Sistem pengendalian internal berpengaruh terhadap kinerja kepala desa.

\section{Pengaruh Motivasi Terhadap Kinerja Kepala Desa}

(Kanfer \& Ackerman, 1989) mengatakan bahwa, motivasi merupakan dorongan untuk mengeluarkan usaha penuh dalam melaksanakan sebuah tugas guna mencapai tujuan tertentu dan mempertahankan dorongan tersebut selama mungkin. Dibutuhkan usaha dalam memaksimalkan dorongan tersebut, mulai dari perhatian, usaha dan ketahanan dalam melaksanakan tanggung jawab. Hal ini didukung oleh penelitian yang dilakukan oleh (arimbawa \& Dewi, 2013) Kumar dan Garg (2010) serta (Oluseyi \& Hammed, 2009) yang mengatakan bahwa motivasi berpengaruh terhadap kinerja pegawai.

H3 : Motivasi Berpengaruh terhadap Kinerja Kepala Desa

\section{Pengaruh komitmen organisasi terhadap Kinerja Kepala Desa}

Penanaman nilai komitmen organisasi yang kuat dalam diri setiap individu akan berpengaruh terhadap kinerja yang akan dihasilkannya, komitmen tidak hanya tentang loyalitas namun juga penanaman nilai-nilai yang dipercayakan pada seseorang. Rasa bertanggungjawab akan wewenang dan tugas yang diberikan akan memiliki dampak positif bagi prestasi kerja. Hal ini didukung dengan hasil penelitian oleh (Fahdi, 2015) dan (Wulandari, 2013).

H4 : Komitmen organisasi berpengaruh terhadap Kinerja Kepala Desa

\section{Populasi dan Sampel}

\section{METODE}

(Sekaran \& Bougie, 2011) Populasi merupakan sekelompok orang, peristiwa, kejadian, atau hal menarik yang ingin peneliti investigasi. Populasi dalam penelitian ini adalah kepala desa yang berada di Kabupaten Kampar dan Kabupaten Kuantan Singingi yang berjumlah 120.

Sampel merupakan bagian dari jumlah dan karakteristik yang dimiliki oleh populasi tersebut (Sugiyono, 2010) Metode yang digunakan dalam penelitian ini yaitu metode Purpossive sampling, dimana dalam metode ini pemilihan sampel dipilih berdasarkan kriteria-kriteria tertentu. Sampel 
yang digunakan dalam penelitian ini berjumlah 60 kepla desa yang terdiri dari desa dengan kategorei berkembang, tertinggal dan maju. Dengan mapping terhadap desa yang dapat dijangkau, efektif dan ekonomis. Hal ini dilakukan guna mengukur tingkat kinerja dari berbagai desa dengan kategori berbeda.

\section{Teknik Pengumpulan Data}

Teknik pengumpulan data dalam penelitian ini menggunakan angket atau kuisioner. Sugiyono (2010:142) mengatakan bahwa kuisioner merupakan teknik pengumpulan data yang dilakukan dengan cara memberi seperangkat pertanyaan atau pernyataan tertulis kepada responden. Data dari kuisioner selanjutnya akan diolah dengan SPSS 23.

\section{Hasil Uji Validitas dan Realibilats Data}

\section{HASIL}

Uji validitas data digunakan untuk mengukur sah atau tidak suatu kuesioner. Dimana keseluruhan variabel penelitian terdiri dari 62 pertanyaan yang harus dijawab oleh responden. Uji signifikansi dilakukan dengan membandingkan nilai $\mathrm{r}$ hitung dengan $\mathrm{r}$ tabel untuk degree of freedom $(\mathrm{df})=\mathrm{n}-2$ dengan alpha 0,05, dalam hal ini $\mathrm{n}$ adalah jumlah sampel (Ghozali, 2013:53). Dalam penelitian ini $\mathrm{df}=\mathrm{n}-2(62-2)=60$, sehingga didapat $\mathrm{r}$ tabel untuk df $(60)=0,2632$

Uji Realibilitas dimaksudkan untuk mengetahui adanya konsistensi alat ukur dalam penggunaannya atau dengan kata lain alat ukur tersebut mempunyai hasil yang konsisten apabila digunakan berkali - kali pada waktu yang berbeda.

Tabel 1. Hasil Uji validitas

\begin{tabular}{|c|c|c|l|}
\hline Butir Pernyataan & r hitung & r table & Keterangan \\
\hline Y.1 & 0,595 & 0.2632 & Valid \\
\hline Y.2 & 0,508 & 0.2632 & Valid \\
\hline Y.3 & 0,646 & 0.2632 & Valid \\
\hline Y.4 & 0,745 & 0.2632 & Valid \\
\hline Y.5 & 0,837 & 0.2632 & Valid \\
\hline Y.6 & 0,797 & 0.2632 & Valid \\
\hline Y.7 & 0,773 & 0.2632 & Valid \\
\hline Y.8 & 0,762 & 0.2632 & Valid \\
\hline Y.9 & 0,829 & 0.2632 & Valid \\
\hline
\end{tabular}

Tabel 2. Hasil Uji Reliabilitas

\begin{tabular}{|l|l|}
\hline \multicolumn{2}{|l|}{ Reliability Statistics } \\
\hline Cronbach's Alpha & N of Items \\
\hline .888 & 9 \\
\hline
\end{tabular}

Dari tabel di atas terlihat bahwa masing-masing butir pernyataan untuk kinerja aparatur diatas kriteria 0,2632 ( $\mathrm{r}$ tabel). jadi dapat disimpulkan bahwa secara statistik masing - masing indikator pernyataan untuk variabel kinerja apartur adalah valid dan layak untuk digunakan sebagai data penelitian.

\section{Hasil Uji Normalitas}

Hasil uji normalitas bertujuan untuk menguji apakah dalam model regresi variabel pengganggu atau residual memiliki distribusi normal. Untuk menentukan normalitas residual digunakan metode yang lebih handal yaitu dengan melihat normal probability plot yang membandingkan distribusi kumulatif dari distribusi normal (Ghozali, 2018) 


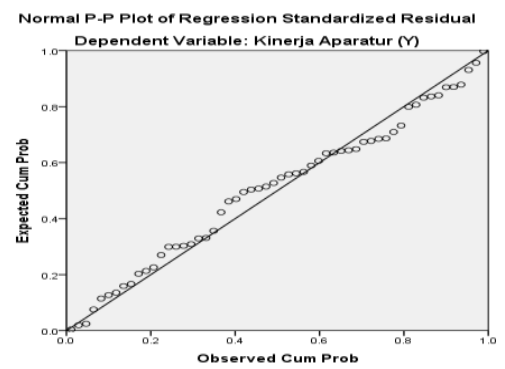

Gambar 2. Normal Probability Standardized Residual

Sumber: Data Primer olahan, 2020

\section{Hasil Uji Multikolinieritas}

Uji Multikolinearitas bertujuan untuk membuktikan atau menguji apakah dalam suatu model regresi ditemukan adanya kolerasi antar variabel bebas (independen). Model regresi yang baik seharusnya tidak terjadi korelasi diantara variabel independen. Jika variabel independen saling berkorelasi, maka variabel -variabel ini tidak ortogonal (Ghozali, 2018).

Tabel 3. Nilai Multikolinearitas Tolerance dan VIF

\begin{tabular}{|c|c|c|c|}
\hline \multirow{2}{*}{\multicolumn{2}{|c|}{ Model }} & \multicolumn{2}{|c|}{ Collinearity Statistics } \\
\hline & & \multirow{2}{*}{ Tolerance } & \multirow{2}{*}{$\mathrm{VIF}$} \\
\hline \multirow{2}{*}{ (Constant) } & & & \\
\hline & .541 & .920 & 1.087 \\
\hline$(\mathrm{X} 1)$ & .610 & .889 & 1.125 \\
\hline \multirow{4}{*}{$\begin{array}{l}\text { SPI (X2) } \\
\text { Motivasi (X3) } \\
\text { Komitmen (X4) } \\
\text { Model }\end{array}$} & .579 & .761 & 1.314 \\
\hline & .890 & .943 & 1.060 \\
\hline & Collinearity Statistics & .912 & 1.097 \\
\hline & Tolerance & .859 & 1.164 \\
\hline
\end{tabular}

\section{(Constant)}

\section{Sumber: Data Primer Olahan, 2020}

Dari tabel di atas, dapat dilihat bahwa VIF untuk seluruh variabel bebas $<10$ dan begitu juga nilai tolerance $>0,10$. Hal ini dapat disimpulkan bahwa model regresi tersebut bebas dari multikolinearitas.

\section{Hasil Uji Heterokedastisitas}

Model regresi yang baik adalah yang homoskedastisitas atau tidak terjadi heteroskedastisitas. Untuk mendeteksi ada tidaknya heteroskedastisitas dilakukan dengan melihat ada tidaknya pola tertentu pada pola scatterplot antar SRESID dan ZPRED dimana sumbu Y adalah Y yang telah diprediksi, dan sumbu $\mathrm{X}$ adalah residual ( $\mathrm{Y}$ prediksi - Y sesungguhnya) yang telah di studentized. Dasar pengambilan keputusan jika ada pola tertentu, seperti titik-titik yang ada membentuk pola tertentu yang teratur (bergelombang, meleber, kemudian menyempit), maka diindikasikan telah terjadi heteroskedastisitas. Jika tidak ada pola yang jelas, serta titk-titik menyebar diatas dan di bawah angka nol pada sumbu Y, maka tidak terjadi heteroskedastisitas (Ghozali, 2013:139).

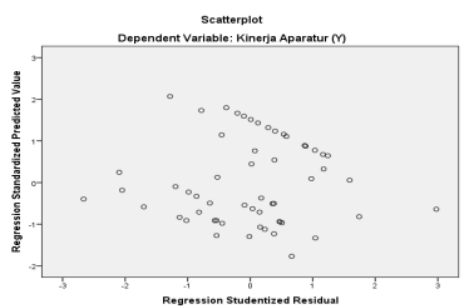

Sumber: Data Primer Olahan, 2020

Gambar 3. Heterokedastisitas Scatter Plot 
Dari gambar grafik Scatterplot diatas, terlihat bahwa titik-titik angka membentuk pola tertentu berupa garis.

\section{Hasil Uji T (Uji Secara Parsial)}

Dalam uji $t$ ini kita dapat melihat apakah setiap variabel bebas berpengaruh terhadap variabel terikatnya. Apabila t tabel $>\mathrm{t}$ Hitung, maka H0 diterima. Dan apabila $\mathrm{t}$ tabel $<\mathrm{t}$ hitung, maka $\mathrm{H} 1$ diterima, begitu jyga dengan sig $>\dot{\alpha}(0,05)$, maka H0 diterima H1 ditolak dan jika sig < $\alpha(0,05)$, maka $\mathrm{H} 0$ ditolak $\mathrm{H} 1$ diterima.Nilai $\mathrm{t}$ table dalam penelitian ini adalah: $\mathrm{t}_{\text {tabel }}=\mathrm{n}-\mathrm{k}-1: \alpha / 2=60-4$ $-1: 0,05 / 2=2.004$

Tabel 4. Hasil uji T

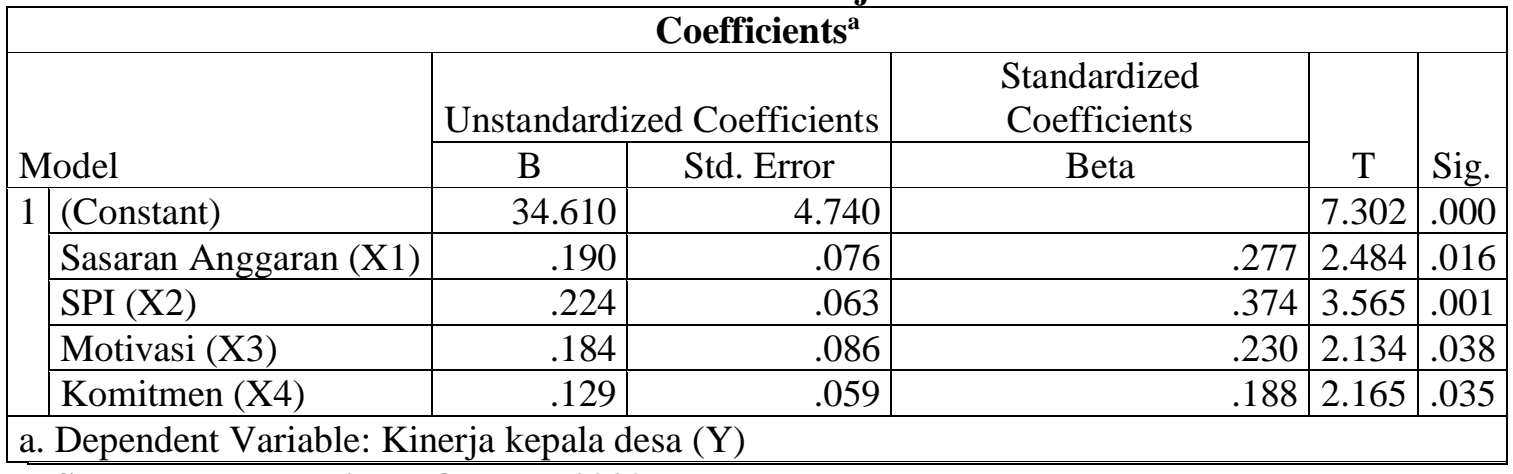

Sumber : Data Primer Olahan, 2020

Hipotesis 1 (H1) tergambar dari tabel di atas dimana terlihat bahwa Sasaran Angaran (X1) memiliki nilai $t_{\text {hitung }} 2.484>t_{\text {tabel }} 2.004$ dan sig. $0,000<0,05$. Artinya variabel kejelasan sasaran angaran $\left(X_{1}\right)$ berpengaruh terhadap kinerja kepala desa $(\mathrm{Y})$, artinya Ho ditolak dan $\mathrm{H}_{1}$ diterima. Hipotesis $2(\mathrm{H} 2)$ dapat dilihat dari tabel bahwa sistem pengendalian internal (X2) memiliki nilai $t_{\text {hitung }} 3.565>t_{\text {tabel }}$ 2.004 dan sig. $0,000<0,05$. Hal ini menunjukkan bahwa variabel sistem pengendalian internal (X2) memiliki pengaruh terhadap kinerja kepala desa (Y). artinya Ho ditolak dan $\mathrm{H} 2$ diterima. Hipotesis 3 (H3) dapat terlihat pada tabel bahwa variabel motivasi (X3) memiliki nilai $t_{\text {hitung }} 2.134>t_{\text {tabel }}$ 2.004 dan sig. $0,000<0,05$. Artinya variabel motivasi $\left(\mathrm{X}_{3}\right)$ memiliki pengaruh terhadap kinerja kepala desa (Y), artinya Ho ditolak dan $\mathrm{H}_{3}$ diterima. Dan yang terakhir Hipotesis 4 (H4) dilihat dari tabel 1, bahwa variabel komitmen organisasi (X4) memiliki nilai thitung $2.165>t_{\text {tabel }} 2.004$ dan sig. $0,000<0,05$. Artinya variabel motivasi $\left(\mathrm{X}_{4}\right)$ memiliki pengaruh terhadap kinerja kepala desa $(\mathrm{Y})$, artinya $\mathrm{Ho}$ ditolak dan $\mathrm{H}_{4}$ diterima.

\section{Hasil uji Koefisien determinasi $\left(R^{2}\right)$}

Perhitungan koefisien determinasi digunakan untuk mengetahui besarnya kontribusi setiap variabel dependen terhadap variabel independen. Hasil uji koefisien determinasi dapat dilihat dari tabel berikut:

Tabel 5. Hasil uji koefisien determinasi

\begin{tabular}{|r|r|r|r|}
\hline $\mathrm{R}$ & R Square & $\begin{array}{c}\text { Adjusted R } \\
\text { Square }\end{array}$ & $\begin{array}{c}\text { Std. Error of } \\
\text { the Estimate }\end{array}$ \\
\hline $.811^{\mathrm{a}}$ & .657 & .630 & 2.122 \\
\hline
\end{tabular}

a. Predictors: (Constant), Komitmen (X4), SPI (X2), Motivasi (X3), Sasaran Anggaran (X1)

b. Dependent Variable: Kinerja kepala desa(Y)

Sumber : Data Primer Olahan, 2020

Dari tabel 2 diatas dapat diketahui bahwa nilai $R$ square $\left(R^{2}\right)$ sebesar 0,630 artinya adalah bahwa pengaruh variabel independen terhadap variabel dependen adalah sebesar $63 \%$. Sedangkan sisanya $37 \%$ dipengaruhi oleh variabel lain yang tidak dimasukkan dalam model regresi ini. 


\section{PEMBAHASAN}

\section{Pengaruh Kejelasan Sasaran Anggaran Terhadap Kinerja Kepala Desa}

Dari hasil pengujian hipotesis pertama yaitu variabel kejelasan sasaran anggaran terlihat bahawa Sasaran Angaran (X1) memiliki nilai thitung $2.484>t_{\text {tabel }} 2.004$ dan sig. $0,000<0,05$. Artinya variabel kejelasan sasaran angaran $\left(\mathrm{X}_{1}\right)$ berpengaruh terhadap kinerja kepala desa $(\mathrm{Y})$, artinya Ho ditolak dan $\mathrm{H}_{1}$ diterima. Hal ini menunjukkan bahwa dengan adanya kejelasan sasaran anggaran, maka kepala desa akan dapat lebih memahami sejauh mana tujuan sasaran anggaran dan hal hal terkait yang dibutuhkan guna memberikan informasi kepada setiap anggota organisasi tentang sasaran capaian anggaran dengan model yang lebih mudah dipahami. Dengan adanya kejelasan sasaran anggaran maka target pencapaian sasaran anggaran yang mudah dipahami akan mendorong tingkat efektifitas dan efisiensi dalam bekerja bagi keseluruhan aparatur desa. Hal ini menunjukan dampak positif terhadap kinerja yang akan dihasilkan oleh kepala desa. Hasil penelitian ini mendukung penelitian-penelitian terdahulu yang dilakukan oleh Putra (2013), Darma (2013).

\section{Pengaruh Pengendalian Internal Terhadap Kinerja Kepala Desa}

Dari hasil penelitian dapat ditarik kesimpulan bahwa hipotesis kedua yaitu variabel Sistem pengendalian internal memiliki nilai $t_{\text {hitung }} 3.565>t_{\text {tabel }} 2.004$ dan sig. $0,000<0,05$. Hal ini menunjukkan bahwa variabel sistem pengendalian internal (X2) memiliki pengaruh terhadap kinerja kepala desa (Y). Dengan adanya sistem pengendalian internal di dalam sebuah organisasi akan membantu terwujudnya kinerja yang dihasilkan oleh aparatur desa ke arah yang positif. Sistem Pengendalian internal di desa yang bisa diterapkan seperti adanya musyawarah desa dalam hal perencanaan RPJMDes atau APBDes. Hal ini dilakukan untuk memastikan anggaran desa tepat sasaran kepada masyarakat desa, tidak menguntungkan satu golongan/kelompok atau tidak sesuai aspirasi dan kebutuhan desa sehingga akan mengakibatkan pembangunan desa hanya dinikmati oleh segelintir orang saja. Pengendalian internal yang lemah di dalam sebuah organisasi, terutama pemerintah akan berdampak pada tidak terdeteksinya kecurangan atau ketidaksesuaian proses akuntansi sehingga data yang diperoleh menjadi tidak kompeten. Hasil penelitian ini sejalan dengan penelitian terdahulu yang dilakukan oleh Darma (2013).

\section{Pengaruh Motivasi Terhadap Kinerja Kepala Desa}

Dari hasil penelitian diatas dapat ditarik kesimpulan bahwa motivasi memiliki nilai thitung 2.134 > $t_{\text {tabel }} 2.004$ dan sig. $0,000<0,05$. Artinya variabel motivasi $\left(X_{3}\right)$ memiliki pengaruh terhadap kinerja kepala desa (Y), artinya Ho ditolak dan $\mathrm{H}_{3}$ diterima. Motivasi kerja yang tinggi berpengaruh pada tingkat usaha yang diberikan oleh pegawai untuk bekerja. Artinya, pegawai yang memiliki motivasi kerja lebih tinggi akan melakukan usaha-usaha dengan intensitas lebih makimal untuk menyelesaikan setiap pekerjaannya. Usaha yang lebih keras ini akan berbanding lurus dengan kuantitas dan kualitas pekerjaan yang bisa diselesaikannya. Hal ini akan berpengaruh positif terhadap kinerja pegawai tersebut. Hasil penelitian ini sesuai dengan penelitian terdahulu yang dilakukan oleh Arimbawa dan Dewi (2013) dan Kumar dan Garg (2010).

\section{Pengaruh Komitmen Organisasi Terhadap Kinerja Kepala Desa}

Dari hasil penelitian diatas dapat terlihat bahwa variabel komitmen organisasi (X4) memiliki nilai $\mathrm{t}_{\text {hitung }} 2.165>\mathrm{t}_{\text {tabel }} 2.004$ dan sig. $0,000<0,05$. Artinya variabel motivasi $\left(\mathrm{X}_{4}\right)$ memiliki pengaruh terhadap kinerja kepala desa (Y), artinya Ho ditolak dan $\mathrm{H}_{4}$ diterima. Apabila setiap pegawai atau aparatur negara memiliki komitmen organisasi yang kuat dimana komitmen tidak hanya tentang loyalitas, namun juga penanaman terhadap nilai-nilai yang dipercayakan kepada seseorang sudah sangat tinggi, rasa bertanggungjawab juga akan meningkat maka peningkatan rasa untuk berprestasi dalam bekerja juga akan meningkat. Hal ini didukung oleh penelitian yang dilakukan oleh $\underline{\text { Wulandari (2013), Fahdi (2015) }}$ dan (Melia \& Sari, 2019).

\section{KESIMPULAN}

Berdasarkan hasil penelitian dan pembahasan di atas, maka dapat ditarik kesimpulan bahwa dari 
beberapa factor seperti pemahaman dalam kejelasan sasaran anggaran, penerapan system pengendalian internal, motivasi dan komitmen organisasi sudah diterapkan oleh kepala desa di Kabupaten Kuantan Singingi dan Kabupaten Kampar. Setiap individual kepa desa sudah memiliki kemampuan, keahlian dan pemahaman yang memadai dalam mengelola desa. Dari hasil penelitian juga menggambarkan bahwa variable kejelasan sasaran anggaran, penerapan system pengendalian internal, motivasi dan komitmen organisasi berpengaruh terhadap kinerja kepala desa.

\section{REFERENSI}

Afrida, N. (2013). Pengaruh desentralisasi dan sistem pengendalian intern Pemerintah terhadap kinerja manajerial skpd (studi empiris pada pemerintah kota padang). Jurnal Akuntansi, 1(2).

Aisyah, S. (n.d.). Karmizi, dan Enni Savitri (2014) Pengaruh Good Governance, gaya kepemimpinan, komitmen organisasi dan budaya terhadap kinerja pemerintah daerah (studi pada pemerintah daerah kabupaten kampar). JOM FEKON, l(2).

arimbawa, K., \& Dewi, A. (2013). PENGARUH BUDAYA ORGANISASI, GAYA KEPEMIMPINAN, DAN MOTIVASI KERJA TERHADAP KINERJA KARYAWAN PADA HOTEL JIMBARAN PURI BALI. E-Jurnal Manajemen Universitas Udayana.

Darma, E. S. (2013). Pengaruh kejelasan sasaran anggaran dan sistem pengendalian akuntansi terhadap kinerja manajerial dengan komitmen organisasi sebagai variabel pemoderasi pada pemerintah daerah: studi empiris pada kabupaten dan kota se-Prov. DIY. Universitas Gadjah Mada.

Fahdi, M. (2015). Faktor-Faktor yang mempengaruhi kinerja badan layanan umum di Universitas Riau [The factors are affecting the performance of public service agency at University of Riau]. Jurnal Akuntansi, 4(1), 1-15.

Ghozali, I. (2018). Aplikasi analisis multivariete dengan program IBM SPSS 23.

Indonesia, I. A. (2021). Standar Profesional Akuntansi Publik.

Indonesia, P. R. (2008). Peraturan Pemerintah Republik Indonesia Nomor 60 Tahun 2008 tentang Sistem Pengendalian Intern Pemerintah.

Kanfer, R., \& Ackerman, P. L. (1989). Motivation and cognitive abilities: An integrative/aptitudetreatment interaction approach to skill acquisition. Journal of Applied Psychology, 74(4), 657.

Kenis, I. (1979). Effects of Budgetary Goal Characteristics on Managerial Attitudes and Performance. The Accounting Review, 54(4), 707-721. http://www.jstor.org/stable/245627

Kumar, N., \& Garg, P. (2011). Impact of motivational factors on employee's job satisfaction-A study on some selected organization in Punjab, India. Asian Journal of Management Research, 2(1), 672-683.

Locke, E. A., \& Latham, G. P. (1984). Goal setting: A motivational technique that works!

Mangkunegara, A. A. A. P. (2016). Manajemen sumber daya manusia perusahaan. PT. Remaja Rosdakarya.

Melia, P., \& Sari, V. F. (2019). Pengaruh Akuntabilitas Publik, Kejelasan Sasaran Anggaran Dan Partisipasi Anggaran Terhadap Kinerja Manajerial. Jurnal Eksplorasi Akuntansi, 1(3), 10681079.

Mowday, R. T., Steers, R. M., \& Porter, L. W. (1979). The measurement of organizational commitment. Journal of Vocational Behavior, 14(2), 224-247.

Muzahid, M. (2017). PENGARUH PENGANGGARAN PARTISIPATIF, KEJELASAN SASARAN ANGGARAN TERHADAP KINERJA MANAJERIAL PEMERINTAH KABUPATEN ACEH UTARA. Jurnal Akuntansi (Media Riset Akuntansi \& Keuangan), 5(2), 110-124.

Nazaruddin, I., \& Setyawan, H. (2016). Pengaruh partisipasi penyusunan anggaran terhadap kinerja aparat pemerintah daerah dengan budaya organisasi, komitmen organisasi, motivasi, desentralisasi, dan job relevant information sebagai variabel moderasi. Journal of Accounting and Investment, 12(2), 197-207.

Nurhalimah, Darwanis, \& Abdullah, S. (2013). Pengaruh Partisipasi Penyusunan Anggaran dan Kejelasan Sasaran Anggaran Terhadap Kinerja Aperatur Perangkat Daerah di Pemerintah Aceh. Jurnal Akuntansi Pascasarjana Universitas Syiah Kuala.

Oluseyi, A. S., \& Hammed, T. A. (2009). Influence of work motivation, leadership effectiveness 
and time management on employees' performance in some selected industries in Ibadan, Oyo State, Nigeria. European Journal of Economics, Finance and Administrative Sciences.

Pilipus, R. (2009). Pengaruh Karakteristik Sasaran Anggaran dan Sistem Pengendalian Intern tehadap Kinerja Manajerial Aparat Pemerintah Daerah.

Pridarsanti, K. Y., \& Yuyetta, E. N. A. (2013). Analisis Faktor-Faktor Yang Mempengaruhi Kinerja Pegawai (Studi Empiris pada Pegawai Direktorat Jenderal Perbendaharaan Kementerian Keuangan di Kota Semarang). Fakultas Ekonomika dan Bisnis.

Putra, D. (2013). Pengaruh akuntabilitas publik dan kejelasan sasaran anggaran terhadap kinerja manajerial satuan kerja perangkat daerah (Studi Empiris pada satuan kerja perangkat daerah Kota Padang). Jurnal Akuntansi.

Putri, S. S. E., Hasan, A., \& Rasuli, M. (n.d.). ORGANISASI, KUALITAS SDM, MOTIVASI DAN KOMITMEN ORGANISASI TERHADAP KINERJA PEGAWAI PADA OPD KABUPATEN KAMPAR. Jurnal Akuntansi (Media Riset Akuntansi \& Keuangan), 7(1).

Roberto, A. (2019). No Title. Analisis Kepuasan Masyarakat Dalam Pelayanan Kepala Desa Medan Estate., 1(1), 32-38.

Sekaran, U., \& Bougie, R. (2011). Business Research Methods: A skill-building approach. Chichester: John Wiley\& Sons Ltd.

Sugiyono, D. (2010). Metode penelitian kuantitatif dan R\&D. Bandung: Alfabeta.

Wulandari, N. (2013). Pengaruh Partisipasi Anggaran dan Komitmen Organisasi Terhadap Kinerja Aparat Pemerintah Daerah (Studi Empiris pada Satuan Kerja Perangkat Daerah Kota Padang). Jurnal Akuntansi, 1(1). 